\title{
FAKTOR- FAKTOR YANG MEMPENGARUHI KINERJA GURU EKONOMI PADA SMA NEGERI DI KOTA MAKASSAR
}

\author{
Eka Farmawaty ${ }^{1 *}$, Anwar Ramli ${ }^{2}$, Rahmatullah ${ }^{3}$ \\ ${ }^{1}$ Pendidikan Ilmu Sosial Program Pascasarjana Universitas Negeri makassar \\ Email: ekhafarmawaty@ymail.com \\ ${ }^{2}$ Manajemen Universitas Negeri Makassar \\ Email: anwar288347@yahoo.com \\ ${ }^{3}$ Pendidikan Ekonomi Universitas Negeri Makassar \\ Email: rahmatullah@unm.ac.id \\ *Corresponding author
}

\begin{abstract}
The purpose of this study was to determine the number of teachers, principals, work motivation, environment and teacher's welfare on economic performance in public high schools in Makassar City as a whole and simultaneously. Data collection techniques are carried out through questionnaire techniques and documentation. Data analysis techniques are Normality Test, Multiple Linear Regression Analysis, T-Test and F Test. The results showed that partially and simultaneously teacher competency, principal leadership, teacher work motivation, work environment and teacher welfare had a significant and significant effect on the performance of economic teachers in public high schools in Makassar City.
\end{abstract}

Keywords: Teacher competency; principal leadership; work motivation; work environment; teacher welfare and teacher performance.

\begin{abstract}
Abstrak. Tujuan penelitian ini adalah untuk mengetahui besarnya pengaruh kompetensi guru, kepemimpinan kepala sekolah, motivasi kerja guru, lingkungan kerja dan kesejahteraan guru terhadap kinerja guru ekonomi pada SMA Negeri di Kota Makassar secara parsial dan simultan. Teknik pengumpulan data dilakukan melalui teknik kuesioner dan dokumentasi.Teknik analisis data yang digunakan adalah Uji Normalitas, Analisis Regresi Linear Berganda, Uji-t dan Uji F. Hasil penelitian menunjukkan bahwa secara parsial dan simultan kompetensi guru, kepemimpinan kepala sekolah, motivasi kerja guru, lingkungan kerja dan kesejahteraan guru berpengaruh dan signifikan terhadap kinerja guru ekonomi pada SMA Negeri di Kota Makassar.
\end{abstract}

Kata Kunci: Kompetensi guru, kepemimpinan kepala sekolah, motivasi kerja, lingkungan kerja, kesejahteraan guru dan kinerja guru

\section{PENDAHULUAN}

Pembangunan nasional merupakan proses yang berlangsung secara dinamis, yangbertujuan untuk mewujudkan sumber daya manusia yang berkualitas dan berdaya saing. Tujuan pembangunan nasional dapat terwujud apabila seluruh elemen- elemen pembangunan dapat berkontribusi termasuk elemen pendidikan, baik pendidikan formal maupun non formal.

Jika gurunya berkualitas baik, maka pendidikan juga akan baik, jika tindakan para guru dari hari ke hari bertambah baik, maka akan menjadi lebih baik pulalah keadaan dunia pendidikan, khususnya dalam mencetak generasi yang terdidik. Hal ini karena aktifitas atau perilaku yang dilakukan manusia merupakan cerminan dari pengetahuan dan pemahaman yang telah diperoleh melalui proses pembelajaran dari gurunya (Rahmatullah, 2018). Oleh karena itu, guru merupakan komponen penting dalam menentukan mutu pendidikan, kesiapan guru dalam melaksanakan tugas profesinya diantaranya mendidik, mengajar, dan melatih harus didukung dengan kompetensi yang menunjang profesinya yang selalu dituntut untuk menghasilkan kinerja yang baik.

"Kinerja guru sangat penting untuk diperhatikan dan dievaluasi karena guru mengemban tugas profesional. Artinya, tugas- 
tugas hanya dapat dikerjakan dengan kompetensi khusus yang diperoleh melalui program pendidikan" (Susanto, 2016: 75).

Untuk memperkuat peran guru dalam melaksanakan pendidikan, sehingga guru mampu memberikan dan juga meningkatkan mutu pendidikan di Indonesia maka dilakukan UKG (Uji Kompetensi Guru). Pemerintah menegaskan bahwa perolehan hasil UKG pada Tabel 1. Hasil Uji Kompetensi Guru SMA di Kota Makassar Tahun 2015

\begin{tabular}{lrcc}
\hline \multicolumn{1}{c}{ Status Sertifikasi } & Jumlah Peserta & Nilai rata- rata 55 & \% \\
\hline Sudah Sertifikasi & 1.197 orang & 641 orang & 53.55 \\
Belum Sertifikasi & 527 orang & 353 orang & 66.98 \\
\hline
\end{tabular}

Sumber Data: Diolah

Berdasarkan Tabel 1 mengenai hasil uji kompetensi guru (UKG) SMA di Kota Makassar tahun 2015 menunjukkan bahwa nilai kompetensi guru yang telah disertifikasi di Kota Makassar belum dapat mencapai `nilai rata- rata yang ditargetkan oleh pemerintah sebesar 55\%.

Mengingat pentingnya kinerja yang berkaitan dengan keberhasilan guru dalam meningkatkan kualitas pn, maka perlu dicari faktor- faktor yang dapat mempengaruhi kinerja guru. Karena banyaknya faktor- faktor tersebut, maka dipilih beberapa faktor yang dimungkinkan akan berpengaruh terhadap kinerja guru dalam melaksanakan tugasnya antara lain: kompetensi guru, kepemimpinan kepala sekolah, motivasi kerja guru, lingkungan kerja guru dan kesejahteraan guru.

SMA Negeri yang berada di Kota Makassar merupakan instansi lembaga pendidikan milik pemerintah di mana tenaga kependidikannya didominasi oleh pegawai negeri sipil yang digaji oleh pemerintah. Dalam Undang- Undang Nomor 43 Tahun 1999 tentang Pokok-Pokok Kepegawaian, Pasal 7 ayat (1) dikemukakan sebagai berikut: "setiap pegawai negeri berhak memperoleh gaji yang adil dan layak sesuai dengan beban pekerjaan dan tanggung jawabnya". Selanjutnya ayat (2) dikemukakan: "gaji yang diterima oleh pegawai negeri harus mampu memacu produktivitas dan menjalin kesejahteraannya"

Berdasarkan latar belakang yang dikemukakan di atas maka rumusan masalah dalam penelitian ini adalah bagaimanakah pengaruh secara parsial dan simultan kompetensi guru, kepemimpinan kepala sekolah, motivasi kerja, lingkungan kerja, dan kesejahteraan guru terhadap kinerja guru ekonomi pada SMA Negeri di Kota Makassar? masing- masing guru menjadi bagian dari penilaian kinerja, selain itu digunakan sebagai bahan pertimbangan kebijakan dalam program pembinaan dan pengembangan profesi serta pemberian penghargaan dan apresiasi kepada guru. Berikut hasil UKG SMA di Kota Makassar pada tahun 2015 dapat dilihat pada tabel berikut:
Kinerja adalah hasil kerja dan perilaku kerja.Jika kinerja berdasarkan hasil maka yang dilihat adalah jumlah kualitas dan kuantitas yang dihasilkan oleh seseorang namun jika dilihat dari perilaku kerja, maka yang dinilai adalah perilaku karyawan dalam menjalankan kewajibannya yang berkontribusi secara positif maupun negatif terhadap pemenuhan tujuan organisasi. Kinerja merupakan karakteistik individu, seperti bakat atau kemampuan, tetapi merupakan perwujudan dari bakat dan kemampuan itu sendiri. Menurut Priansa (2014:79) "kinerja merupakan hasil kerja yang dicapai guru di sekolah dalam rangka mencapai tujuan sekolah". Guru yang memiliki level kinerja tinggi merupakan guru yang memiliki produktivitas kerja sama di atas standar yang ditentukan, begitupun sebaliknya, guru tersebut merupakan guru yang tidak produktif.

Menurut Kepmendiknas No.045/U/2002 "kompetensi adalah seperangkat tindakan cerdas, penuh tanggung jawab, yang dimiliki seseorang sebagai syarat untuk dianggap mampu oleh masyarakat dalam melaksanakan tugastugas dibidang pekerjaan tertentu". Susanto (2016:135) mengemukakan bahwa "kompetensi adalah seperangkat pengetahuan, keterampilan dan perilaku yang harus dimiliki, dihayati dan dikuasai oleh guru untuk dapat melaksanakan tugas- tugas profesionalnya". Usman dalam Susanto (2016:135) juga mengemukakan bahwa "kompetensi adalah suatu hal yang menggambarkan kualifikasi atau kemampuan seseorang".

Menurut Permendiknas No 16 Tahun 2007 tentang standar kualifikasi akademik dan

\section{Kinerja Guru} yang memiliki level kinerja rendah, maka guru

\section{Kompetensi Guru}


kompetensi guru. Standar kompetensi guru terdiri dari empat komponen utama yaitu:

a. Kompetensi pedagogik adalah kemampuan guru berkenaan dengan penguasaan teori, dan praktis dalam pembelajaran seperti kemampuan mengelola pembelajaran, perencanaan dan pelaksanaan pembelajaran, evaluasi hasil belajar, dan pengembangan peserta didik untuk mengaktualisasikan berbagai potensi yang dimilikinya.

b. Kompetensi kepribadian adalah kemampuan kepribadian yang mantap, stabil, dewasa, arif, dan berwibawa, menjadi teladan peserta didik dan berakhlak mulia.

c. Kompetensi sosial, kompetensi ini berkaitan dengan kemampuan guru dalam berinteraksi dengan peserta didik dan orang disekitarnya.

d. Kompetensi profesional adalah kemampuan dasar tenaga pendidik jika ia mampu menguasai keahlian dan keterampilan teoretik dan praktik dalam proses pembelajaran. Meliputi penguasaan materi, pemanfaatan teknologi informasi, meningkatkan kinerja profesionalnya serta komitmen dalam pengabdian kepada masyarakat.

\section{Kepemimpinan Kepala Sekolah}

Kepala sekolah sebagai pemimpin pembelajaran dalam meningkatkan pembelajaran di sekolahnya akan mencurahkan sebagian besar waktunya bagi pengembangan guru, dan apabila seorang guru telah mendapatkan perhatian yang lebih dalam kegiatan pembelajaran yang dilakukannya, maka menurut Susanto (2016:29) "hal itu dapat meningkatkan kinerja mengajarnya". Kepemimpinan pembelajaran sebagai upaya memimpin guru agar mengajar lebih baik dan pada akhirnya akan memperbaiki prestasi belajar peserta didik.

Kepala sekolah adalah pemimpin pendidikan yang mempunyai peranan sangat besar dalam pengembangan mutu pendidikan di sekolah. Sehingga kepala sekolah harus mampu meningkatkan semangat kerja guru yang kemudian akan berdampak terhadap kinerja guru tersebut.

\section{Motivasi Kerja}

Makin termotivasi seseorang untuk melakukan suatu pekerjaan maka kinerjanya akan meningkat, demikian pula sebaliknya Seperti yang dikemukakan oleh Hasibuan dalam Septidira, dkk (2013:685) bahwa "motivasi sebagai pemberian daya penggerak yang menciptakan kegairahan kerja seseorang agar mereka ingin bekerja sama, bekerja efektif dan terintegrasi dengan segala upayanya untuk mencapai kepuasan". Pada akhirnya dorongan tersebut akan menghasilkan kinerja yang baik, demikian pula sebaliknya.

Adapun faktor-faktor yang memengaruhi motivasi kerja guru menurut Roth, dkk dalam Dewi (2015:28) yaitu:

a. Motivasi ekstrinsik yang meliputi:

a) Penghargaan atas usaha dan prestasi guru

b) Kepuasan terhadap cara mengajar

c) Pengamatan kepala sekolah terhadap pekerjaan guru

b. Motivasi instrinsik yang meliputi:

a) Cara mengajar yang menyenangkan

b) Hubungan dengan orang tua yang harmonis

c) Hubungan dengan siswa yang harmonis

\section{Lingkungan Kerja}

Lingkungan kerja merupakan salah satu faktor yang penting dalam peningkatan kinerja guru karena dengan lingkungan yang mendukung, baik suasana maupun sarana dan prasarana akan menjadikan guru untuk lebih giat bekerja. Seorang guru yang merasa senang dengan lingkungan kerjanya maka perhatian, imajinasi dan keterampilan dalam melaksanakan pekerjaannya tentu akan meningkat pula. Sebaliknya jika merasa tidak senang dan nyaman dengan lingkungannya maka kinerjanya pun dapat menurun.

Menurut Sedarmayanti dalam Pratama (2015:353) mengemukakan bahwa secara garis besar, jenis lingkungan kerja terbagi menjadi dua, yaitu:

1. Lingkungan kerja fisik

Lingkungan kerja fisik adalah semua keadaan yang berbentuk fisik yang terdapat disekitar tempat kerja yang dapat mempengaruhi karyawan baik secara langsung maupun tidak langsung.

2. Lingkungan kerja non fisik

Lingkungan kerja non fisik adalah semua keadaan yang terjadi yang berkaitan dengan hubungan kerja baik, hubungan dengan atasan, maupun hubungan sesama rekan kerja, ataupun hubungan dengan bawahan.

\section{Kesejahteraan Guru}

Bentuk kesejahteraan guru tidak harus selalu berupa gaji, melainkan imbalan materil lain, seperti asuransi kesehatan, pemberian insentif diluar kegiatan mengajar guru, program 
pensiun dan sebagainya akandapat meringankan beban ekonomi para guru.

Dalam Undang- Undang No.14 tahun 2005 tentang guru dan dosen yang disahkan pada 30 Desember 2005 menyebutkan bahwa "guru wajib memiliki kualifikasi akademik, kompetensi, sertifikat pendidik, sehat jasmani dan rohani, serta memiliki kemampuan untuk mewujudkan tujuan pendidikan nasional". Menurut Zulkifli, dkk (2014:148) "sertifikasi adalah proses pemberian sertifikat kepada guru yang telah memenuhi standar profesionalitas guru dan kinerja guru dapat diprediksi melalui kesejahteraan guru".

Seorang guru akan tenang menjalankan tugasnya bila beban ekonomi keluarga secara minimal sudah terpenuhi, sebaliknya bila beban itu tidak terpenuhi, maka konsentrasinya dalam menjalankan tugas akan terganggu.

\section{METODE PENELITIAN}

Penelitian ini adalah termasuk penelitian survey dengan menggunakan pendekatan deskriptif kuantitatif yaitu penelitian yang memberikan gambaran secara jelas dan sistematis mengenai data- data yang ada di lapangan untuk menjelaskan seberapa besar pengaruh antara variabel independen terhadap variabel dependenpada SMA Negeri di Kota Makassar.Penelitian ini dilakukan pada semua SMA Negeri yang ada di Kota Makassar yang terdiri atas 23 sekolah

Dalam penelitian ini, semua populasi dijadikan sampel, hal ini untuk menentukan secara tepat keadaan populasi yang jumlahnya sedikit. Oleh karena itu penelitian ini merupakan penelitian populasi. Adapun sampel dalam penelitian ini adalah kepala sekolah atau tim penilai kinerja guru yang dibentuk oleh kepala sekolah dan guru ekonomi yang bertugas pada tahun 2018 pada SMA Negeri di Kota Makassar baik yang telah PNS maupun non PNS.

Metode yang digunakan adalah menggunakan angket dengan lima alternatif jawaban. Dalam angket tersebut peneliti memberikan angka atau bobot untuk item-item pertanyaan/ pernyataan dengan menggunakan skala Likert, di mana responden akan diminta untuk menyatakan kesetujuan atau ketidak setujuannya terhadap isi pertanyaan/ pernyataan.

Uji coba instrumen yang dilakukan adalah analisis keabsahan data yang terdiri atas uji validitas dan uji reliabilitas.Sedangkan untuk teknik analisis data menggunakan uji normalitas, dan analisis statistik data yang terdiri atas regresi linear berganda dan pengujian hipotesis Uji $\mathrm{F}$ dan Uji-t.

Berdasarkan uji validasi menunjukkan semua item pertanyaan dari setiap variabel yang dikaji dalam penelitian ini adalah valid ditunjukkan melalui nilai sig. (2-tiled) kurang dari 0,05. Selain itu nilai Pearson Correlation untuk semua item pertanyaan pada masingmasing variabel memiliki tanda bintang. Sedangkan dari pengujian realibilitas instrumen penelitian, menunjukkan cronbach's alpha $>0,50$ maka dapat disimpulkan bahwa instrumen yang digunakan dalam penelitian ini memiliki tingkat konsistensi jawaban responden yang layak atau reliabel.

\section{HASIL DAN PEMBAHASAN}

\section{Uji Normalitas}

Untuk uji normalitas menunjukkan nilai asymp. Sig.(2-tailed) variabel kompetensi guru sebesar 0,359, untuk variabel kepemimpinan kepala sekolah sebesar 0,584, untuk variabel motivasi kerja guru sebesar 0.085, untuk variabel lingkungan sekolah sebesar 0,299, untuk variabel kesejahteraan guru sebesar 0,327 dan untuk variabel kinerja guru sebesar 0,622. Dari hasil uji normalitas dapat diperhatikan asymp. Sig. lebih besar dari 0,05 sehingga dapat disimpulkan bahwa data terdistribusi secara normal.

\section{Uji F (Uji Simultan)}

Untuk menguji pengaruh variabel bebas secara bersama- sama diuji dengan menggunakan uji $\mathrm{F}$ dengan menggunakan SPSS 20.0

Tabel 2. Hasil Uji Simultan (Uji F)

\begin{tabular}{lrrrrc}
\hline Model & Sum of Squares & \multicolumn{1}{c}{ DF } & Mean Square & F & Sig \\
\hline Regresion & 2104.99 & 5 & 420.998 & 30.949 & 0.000 \\
Residul & 666.537 & 49 & 13.603 & & \\
\hline Total & 2771.527 & 54 & & & \\
\hline
\end{tabular}

Sumber: Hasil Olah Data SPSS 2018 
Berdasarkan hasil uji $\mathrm{F}$ menunjukkan nilai dengan menggunakan taraf signifikansi $\alpha=0,05$ adalah Sig sebesar 0,000 lebih kecil dari 0,05 , maka hal ini menunjukkan bahwa model yang digunakan untuk membuat interpretasi adalah signifikan. Ini menunjukkan bahwa $\mathrm{H} 0$ ditolak dan H1 diterima. Dengan demikian kompetensi guru, kepemimpinan sekolah, motivasi kerja guru, lingkungan kerja dan

Tabel 3. Hasil Uji Parsial (Uji-t) kesejahteraan guru berpengaruh secara bersamasama terhadap kinerja guru ekonomi pada SMA Negeri di Kota Makassar.

\section{Uji Parsial (Uji- t)}

Uji Parsial (Uji- t) dilakukan untuk mengetahui apakah masing- masing variabel independen mempunyai pengaruh terhadap variabel dependen.

\begin{tabular}{lccc}
\hline \multicolumn{1}{c}{ Model } & $\begin{array}{c}\text { Standardized } \\
\text { Coefficient } \\
\text { Beta }\end{array}$ & T & Sig \\
\hline Contant & & 1.956 & 0.056 \\
Kompetensi Guru & 0.249 & 2.568 & 0.013 \\
Kepemimpinan Kepala Sekolah & 0.219 & 2.178 & 0.034 \\
Motivasi Kerja Guru & 0.235 & 2.780 & 0.008 \\
Lingkungan Sekolah & 0.185 & 2.147 & 0.037 \\
Kesejahteraan Guru & 0.253 & 2.712 & 0.009 \\
\hline
\end{tabular}

Sumber: Hasil Olah Data SPSS 2018

Berdasarkan hasil uji-t yang diperoleh menunjukkan bahwa variabel bebas yaitu untuk variabel kompetensi guru, kepemimpinan kepala sekolah, motivasi kerja guru, lingkungan kerja dan kesejahteraan guru terhadap variabel terikat kinerja guru memiliki nilai signifikansi lebih kecil dari 0.05. Hal ini dapat disimpulkan bahwa H1 diterima dan

H0 ditolak, dengan demikian variabel b ebas mempunyai pengaruh yang signifikan terhadap

Tabel 4. Hasil Analisis Uji Koefisien Determinasi kinerja guru ekonomi pada SMA Negeri di Kota Makassar.

\section{Uji Koefisien Determinasi}

Uji koefisien determinasi digunakan untuk mengukur proporsi atau persentase sumbangan variabel independen yang diteliti terhadap variasi naik turunnya variabel dependen. Berikut hasil uji koefisien determinasi menggunakan SPSS 20.0 for windows.

\begin{tabular}{rrrrr}
\hline Model & R & R Square & Adjusted R Square & Std. Error of the Estimate \\
\hline 1 & 0.871 & 0.760 & 0.735 & 3.6882 \\
\hline
\end{tabular}

Sumber: Hasil Olah Data SPSS 2018

Berdasarkan Tabel 4 hasil analisis data menunjukkan bahwa variabel kompetensi guru, kepemimpinan kepala sekolah, motivasi kerja guru, lingkungan sekolah, dan kesejahteraan guru mempunyai pengaruh yang signifikan terhadap kinerja guru yang memiliki nilai kontribusi atau pengaruh sebesar 0,760 atau $76 \%$, sedangkan sisanya sebesar $24 \%$ diterangkan oleh variabel lain yang tidak disebutkan pada penelitian ini.

\section{Pembahasan}

\section{Pengaruh Kompetensi Guru Terhadap Kinerja Guru Ekonomi \\ Berdasarkan hasil penelitian} menunjukkan bahwa kompetensi guru memiliki pengaruh positif dan signifikan terhadap kinerja guru ekonomi pada SMA Negeri di Kota Makassar. Temuan ini juga membuktikan bahwa kompetensi guru yang terdiri dari indikator kompetensi pedagogik, kompetensi profesional, kompetensi kepribadian dan kompetensi sosial mempunyai pengaruh positif dan signifikan terhadap kinerja guru. 
Hal tersebut didukung oleh pernyataan dari Sunarso (2016:119) yang menyatakan bahwa "untuk mencapai kinerja yang maksimal perlu didukung dengan kompetensi-kompetensi yang harus dimiliki oleh seorang guru untuk menjalankan keprofesiannya". Sejalan dengan pendapat Kasmir (2016:189) yang menyatakan bahwa " kemampuan dan keahlian akan mempengaruhi kinerja seseorang".

\section{Pengaruh Kepemimpinan Kepala Sekolah Terhadap Kinerja Guru Ekonomi}

Berdasarkan hasil penelitian menunjukkan bahwa kepemimpinan kepala sekolah memiliki pengaruh positif dan signifikan terhadap kinerja guru ekonomi pada SMA Negeri di Kota Makassar.

Kepemimpinan dapat memengaruhi perilaku manusia baik perorang maupun perkelompok demi tercapainya tujuan organisasi. Pimpinan suatu unit kerja harus mampu mempengaruhi perilaku orang lain terutama bawahannya untuk berfikir positif dan bertindak sedemikian rupa sehingga melalui perilaku yang positif ia memberikan sumbangsih nyata dalam pencapaian organisasi, termasuk kepemimpinan kepala sekolah. Seperti yang dikemukakan oleh Mulyasa (2004:20) "kepala sekolah merupakan salah satu komponen pendidikan yang berpengaruh dalam meningkatkan kinerja guru".

\section{Pengaruh Motivasi Kerja Guru Terhadap Kinerja Guru Ekonomi}

Berdasarkan hasil penelitian menunjukkan bahwa motivasi kerja guru memiliki pengaruh positif dan signifikan terhadap kinerja guru ekonomi pada SMA Negeri di Kota Makassar. Hal ini sejalan dengan penelitian yang dilakukan oleh Ratno Nur Suryadi (2017) yang menyimpulkan bahwa terdapat pengaruh positif dan signifikan terhadap kinerja guru ekonomi SMA Negeri di Kota Makassar.

Terkait dengan kinerja guru, apabila seorang guru memiliki dorongan yang kuat dari dalam atau luar dirinya, maka guru akan terangsang untuk melakukan pekerjaannya dengan sebaik mungkin yang kemudian berpengaruh terhadap kinerjanya, seperti yang dikemukakan oleh Kasmir (2016:191) bahwa "motivasi memengaruhi kinerja seseorang".

\section{Pengaruh Lingkungan Kerja Terhadap Kinerja Guru Ekonomi}

Berdasarkan hasil penelitian menunjukkan bahwa lingkungan kerja memiliki pengaruh positif dan signifikan terhadap kinerja guru ekonomi pada SMA Negeri di Kota Makassar. Jika lingkungan kerjanya dapat memberikan rasa nyaman dan memberikan ketenangan maka akan membuat suasana kerja menjadi kondusif, sehingga dapat meningkatkan hasil kerja seseorang menjadi lebih baik karena bekerja tanpa gangguan begitupun sebaliknya.

Seperti yang dikemukakan oleh Kasmir (2016:192) "Lingkungan memengaruhi kinerja seseorang". Susanto (2016:275) juga mengemukakan bahwa "sertifikasi guru jangan sampai dipandang sebagai satu- satunya jalan yang menjamin kualitas guru, sedangkan lingkungan kerja guru tidak mendukung penggunaan maksimal kompetensi”.

\section{Pengaruh Kesejahteraan Guru Terhadap Kinerja Guru Ekonomi.}

Berdasarkan hasil penelitian menunjukkan bahwa kesejahteraan guru memiliki pengaruh positif dan signifikan terhadap kinerja guru ekonomi pada SMA Negeri di Kota Makassar.

Berdasarkan hasil penelitian pada guru ekonomi di SMA Negeri di Kota Makassar indikator variabel kesejahteraan guru yang paling berpengaruh terhadap kinerja guru adalah sertifikasi guru. Menurut Melati, dkk (2013:74) "sertifikasi bertujuan untuk meningkatkan kompetensi guru dan kesejahteraan guru"., sedagkan menurut Zulkifli, dkk (2014:148) "sertifikasi adalah proses pemberian sertifikat kepada guru yang telah memenuhi standar profesionalitas guru dan kinerja guru dapat diprediksi melalui kesejahteraan guru".

\section{SIMPULAN DAN SARAN Simpulan}

Berdasarkan dari hipotesis penelitian, hasil olah data dan pembahasan, maka kita dapat menarik kesimpulan bahwa kompetensi guru, kepemimpinan kepala sekolah, motivasi kerja guru, lingkungan sekolah dan kesejahteraan guru berpengaruh positif dan signifikan terhadap kinerja guru ekonomi pada SMA Negeri di Kota Makassar.

\section{Saran}

Berdasarkan dari hasil penelitian yang telah dilakukan maka peneliti memberikan saran kepada pihak- pihak yang terkait sebagai berikut: 
1. Kepada guru terutama guru ekonomi pada SMA Negeri di Kota Makassar yang telah memiliki kompetensi yang baik, motivasi kerja, lingkungan kerja yang memadai, kesejahteraan guru yang baik, agar terus meningkatkan kinerjanya untuk menciptakan pendidikan yang bermutu.

2. Bagi peneliti yang akan datang, dari hasil analisis penelitian ini dapat dijadikan sebagai pedoman dalam penelitiannya, atau justru dengan kombinasi variabel yang lain dan tempat penelitian yang lebih kompleks.

\section{DAFTAR RUJUKAN}

Dewi, Tiara, Anggia.2015. Pengaruh Profesionalisme Guru dan Motivasi Kerja Guru terhadap Kinerja Guru Ekonomi SMA se-Kota Malang. Jurnal Pendidikan Ekonomi UM Metro, (Online), Vol.3, No.1.(http://download.portalgaruda.org, Diakses 26 Januari 2018).

Kasmir. 2016. Manajemen Sumber Daya Manusia: Teori dan Praktik. Jakarta: PT Rajagrafindo Persada.

Mulyasa. 2004. Kurikulum Berbasis Kompetensi. Bandung : Remaja Rosda Karya.

Pratama, Anggi. 2015. Pengaruh Lingkungan Kerja terhadap kinerja Pegawai pada Badan Pelayanan Perijinan Terpadu dan Penanaman Modal.e-Jurnal Ilmu Administrasi Bisnis, (Online), Vol.3, No.2. (http://ejournal.adbisnis.fisipunmul.ac.id, Diakses 26 Januari 2018).

Priansa, Donni.J. 2014. Kinerja dan Profesionalisme Guru. Bandung: Alfabeta.

Rahmatullah, R. (2018). Pembelajaran Ekonomi Berjatidiri Bangsa. JEKPEND: Jurnal Ekonomi Dan Pendidikan, 1(1), 10-16. https://doi.org/10.26858/jekpend.v1i1. 5055

Septidira,M., Nurazi,R., \& Nasution. 2013. Pengaruh Motivasi, Kepemimpinan dan Budaya Kerja terhadap Kinerja Pegawai. Jurnal Ilmiah Manajemen. (Online),Vol,15,No.5.

(http://repository.unib.ac.id, Diakses 26 Januari 2018).

Susanto, Ahmad. 2016. Konsep Strategi dan Implementasi: Manajemen Peningkatan Kinerja Guru. Jakarta: Prenada Media Group.

Zulkifli, Mohammad., Darmawan, Arif. \& Satrisno, Edy. 2014. Motivasi Kerja, Sertifikasi, kesejahteraan dan Kinerja Guru, Jurnal psikologi Indonesia (Online), Vol 3. No 02 (http://jurnal.untag-sby.ac.id, Diakses 26 Januari 2018 